\title{
Hallucinogens as discriminative stimuli in animals: LSD, phenethylamines, and tryptamines
}

\author{
J. C. Winter
}

Received: 3 July 2008 / Accepted: 24 September 2008 / Published online: 1 November 2008

(C) Springer-Verlag 2008

\begin{abstract}
Background Although man's first encounters with hallucinogens predate written history, it was not until the rise of the sister disciplines of organic chemistry and pharmacology in the nineteenth century that scientific studies became possible. Mescaline was the first to be isolated and its chemical structure determined. Since then, additional drugs have been recovered from their natural sources and synthetic chemists have contributed many more. Given their profound effects upon human behavior and the need for verbal communication to access many of these effects, some see humans as ideal subjects for study of hallucinogens. However, if we are to determine the mechanisms of action of these agents, establish hypotheses testable in human subjects, and explore the mechanistic links between hallucinogens and such apparently disparate topics as idiopathic psychosis, transcendental states, drug abuse, stress disorders, and cognitive dysfunction, studies in animals are essential. Stimulus control by hallucinogens has provided an intuitively attractive approach to the study of these agents in nonverbal species.

Objective The intent of this review is to provide a brief account of events from the time of the first demonstration of hallucinogen-induced stimulus control to the present. In general, the review is limited to lysergic acid diethylamide (LSD) and the hallucinogenic derivatives of phenethylamine and tryptamine.
\end{abstract}

J. C. Winter $(\triangle)$

Department of Pharmacology and Toxicology,

School of Medicine and Biomedical Sciences,

State University of New York at Buffalo,

102 Farber Hall,

Buffalo, NY 14214-3000, USA

e-mail: jcwinter@buffalo.edu
Results The pharmacological basis for stimulus control by LSD and hallucinogenic phenethylamines and tryptamines is serotonergic in nature. The $5-\mathrm{HT}_{2 \mathrm{~A}}$ receptor appears to be the primary site of action with significant modulation by other serotonergic sites including $5-\mathrm{HT}_{2 \mathrm{C}}$ and $5-\mathrm{HT}_{1 \mathrm{~A}}$ receptors. Interactions with other neurotransmitters, especially glutamate and dopamine, are under active investigation. Most studies to date have been conducted in the rat but transgenic mice offer interesting possibilities.

Conclusions Hallucinogen-induced stimulus control provides a unique behavioral tool for the prediction of subjective effects in man and for the elucidation of the pharmacological mechanisms of the action of these agents.

Keywords Hallucinogens · Drug-induced stimulus control · Lysergic acid diethylamide (LSD) · Mescaline .

(-)-2,5-dimethoxy-4-methylamphetamine (DOM) .

Psilocybin $\cdot$ Bufotenine $\cdot N, N$-dimethyltryptamine (DMT) . Phencyclidine (PCP)

\section{Historical perspective}

Hallucinogens, most often in the form of crude botanical extracts, have been known to man for thousands of years (Schultes and Hofmann 1980). However, scientific investigation of these drugs awaited the rise, in the nineteenth century, of organic chemistry and experimental pharmacology. Indeed, it was not until Heffter's (1896) isolation of mescaline in 1896 from the cactus, Lophophora williamsii, and the determination of its chemical structure $(3,4,5-$ trimethoxyphenylethylamine) by Spath (1919) that a welldefined substance could be said to produce hallucinations. In view of the remarkable alterations in thought and perception produced by hallucinogens and because of the 
essentially subjective nature of a major portion of the effects of these drugs, it is not surprising that selfexperimentation played a prominent role in the initial investigation of drugs such as mescaline (Heffter 1897), 3,4-methylenedioxy-alpha-methylphenylethylamine (Alles 1959), lysergic acid diethylamide (LSD; Hofmann 1959), $N, N$-dimethyltryptamine (DMT; Szara 1956, 1957), and psilocybin (Hofmann 1968). No account of the selfadministration of psychoactive drugs would be complete without reference to Ann Shulgin and Alexander Shulgin (1991, 1997), whose personal experiences with an extensive series of tryptamines and phenethylamines are compiled in two volumes. However, even in those instances when adequate experimental designs have been employed in clinical studies (e.g., Gouzoulis-Mayfrank et al. 2005, 2006; Griffiths et al. 2006; Hollister et al. 1968, 1969a, b; Isbell et al. 1961, 1967; Snyder et al. 1968; Vollenweider et al. 1996, 1998a; Wolbach et al. 1962a, b), ethical considerations have placed significant constraints on the type of experiments undertaken. Thus, in seeking what the late Leo Hollister called the Holy Grail of pharmacology, the mechanism of action of drugs, investigators have often turned to infrahuman species. In so doing, certain ethical and legal problems are avoided and a wider range of experimental manipulation becomes permissible but, then, there arise questions of interpretation and extrapolation.

It is generally assumed that the biological events that precede and accompany chemically induced hallucinations in man have some counterpart in lower species. Early infrahuman studies of hallucinogens employed what Peter Dews, the founder of behavioral pharmacology, referred to as "isolated bits of dying tissue." These usually took the form of a section of smooth muscle situated in a tissue bath so that contraction and relaxation might be quantified (e.g., Wooley and Shaw 1954; Winter and Gessner 1968). While studies such as these provided valuable insights into the possible mechanisms of the action of hallucinogens, including a role for serotonin (Gaddum 1953), it was natural to seek behavioral correlates of human hallucinogenesis in animals. In a typical series of experiments, a profile of hallucinogenic activity was drawn using, it sometimes seemed, whatever behavior was at hand. The dependent variables ranged from neuropharmacological indices (Corne and Pickering 1967; Martin and Eades 1970; Silva and Calil 1975) to nonconditioned behavior (Dixon 1968; Schneider and Chenoweth 1970; Silva and Calil 1975) to operant behavior (Smythies and Sykes 1964; Uyeno 1969; Uyeno and Mitoma 1969; Silva and Calil 1975). Consensus as to the predictive ability of these approaches was achieved seldom if ever. It was propitious therefore that Ira Hirschhorn, as a part of his Ph.D. thesis research, successfully trained both LSD and mescaline as discriminative stimuli in the rat (Hirschhorn and Winter
1971). The technique of hallucinogen-induced stimulus control was then transferred, first by Hirschhorn's colleague, Martin Schechter, and then by Hirschhorn himself, to the laboratory of John Rosecrans where it flourished (Glennon et al. 1979; Hirschhorn and Rosecrans 1974; Rosecrans and Glennon 1979; Schechter and Rosecrans 1972) On a purely intuitive basis, the study of the stimulus properties of hallucinogens is more attractive than, for example, analysis of LSD-impaired rope-climbing ability (Winter and Flataker 1956).

\section{Scope of this review}

A dictionary definition of hallucination seems simple enough: a perception of objects with no reality (Webster 1993). That apparent simplicity belies the range of potentially hallucinogenic chemicals and the complexity of human responses to those agents. In deference to that range and to that complexity, this review is restricted to the stimulus effects of LSD, tryptamines, and phenethylamines. Only passing mention will be made of anticholinergics, cannabinoids, exotic agents such as salvinorin, and all those other drugs which properly lay claim to the title hallucinogen. It is true that some attention will be paid to the noncompetitive $N$-methyl-D-aspartate (NMDA) antagonists as represented by phencyclidine (PCP) but only with respect to their possible commonalities with the objects of this review. I have made no attempt to be encyclopedic in my coverage but would direct the interested reader to the comprehensive list of stimulus control studies provided by the Drug Discrimination Bibliographic Database (Stolerman and Kamien 2004), to earlier reviews of hallucinogen-induced stimulus control (Winter 1974; Appel et al. 1982; Glennon 1999; Winter et al. 1999), and to the more general recent reviews of hallucinogens by Nichols (2004) and by Fantegrossi et al. (2008a). I have relied upon the primary literature and have attempted to avoid references to book chapters as these are often difficult to acquire. In general, I have uncritically accepted the conclusions expressed in the papers cited but too often, in my opinion, those conclusions would have been strengthened by statistical analysis. Tests of significance may merely confirm the obvious but in many instances they will rid us of illusions born of random variation. Throughout this review, I will follow the convention, adopted from animal psychophysics, that the stimulus effects of a trained drug generalize to a specified degree to a tested drug, not vice versa. Finally, I will attempt no further definition of hallucinogen beyond saying that if a chemical mimics in human subjects the subjective effects of LSD or a tryptamine such as psilocybin or a phenethylamine such as mescaline, then it is a hallucinogen. 


\section{Chemical classes}

LSD and the tryptamines are often lumped together as "indoleamine hallucinogens". It is true that one can trace within the elegant structure of LSD (Fig. 1) the indole nucleus common to the tryptamines. However, it is equally true that one can find phenethylamine. More important, based on evidence both biochemical and behavioral, LSD and the tryptamines are sufficiently different to justify separate categories. To this end, I here classify LSD as an ergoline (Nichols 2004) to distinguish it from the tryptamines. Figure 2 illustrates tryptamine, an endogenous neurochemical, as well as its hallucinogenic relatives, DMT, 5-methoxy-DMT (5-MeO-DMT), and psilocybin together with its presumed active derivative, psilocin (4hydroxy-DMT). The hallucinogenic efficacy of bufotenine (5-hydroxy-DMT) has been a matter of contention for some time (Shulgin and Shulgin 1997, pages 473-478; Torres and Repke 2006). The phenethylamine hallucinogens (Fig. 3) are simple ring-substituted derivatives either of the endogenous neurochemicals, phenethylamine or amphetamine (alpha-methylphenethylamine). Mescaline is representative of the former neurochemical, 2,5-dimethoxy-4methylamphetamine (DOM) of the latter neurochemical. However, whatever classification scheme is adopted, it is impossible to discuss these groups in isolation because of the overlap between them both experimentally and mechanistically. This is not to say that intriguing differences between the groups do not continue to emerge.

\section{Neurochemical bases of stimulus control by hallucinogens}

Serotonin Soon after the discovery of LSD by Hofmann in 1943 and the identification of serotonin as 5hydroxytryptamine (Rapport 1949), it was recognized (a) that LSD might act via a serotonergic mechanism

Fig. 1 Structure of the ergoline hallucinogen lysergic acid diethylamide
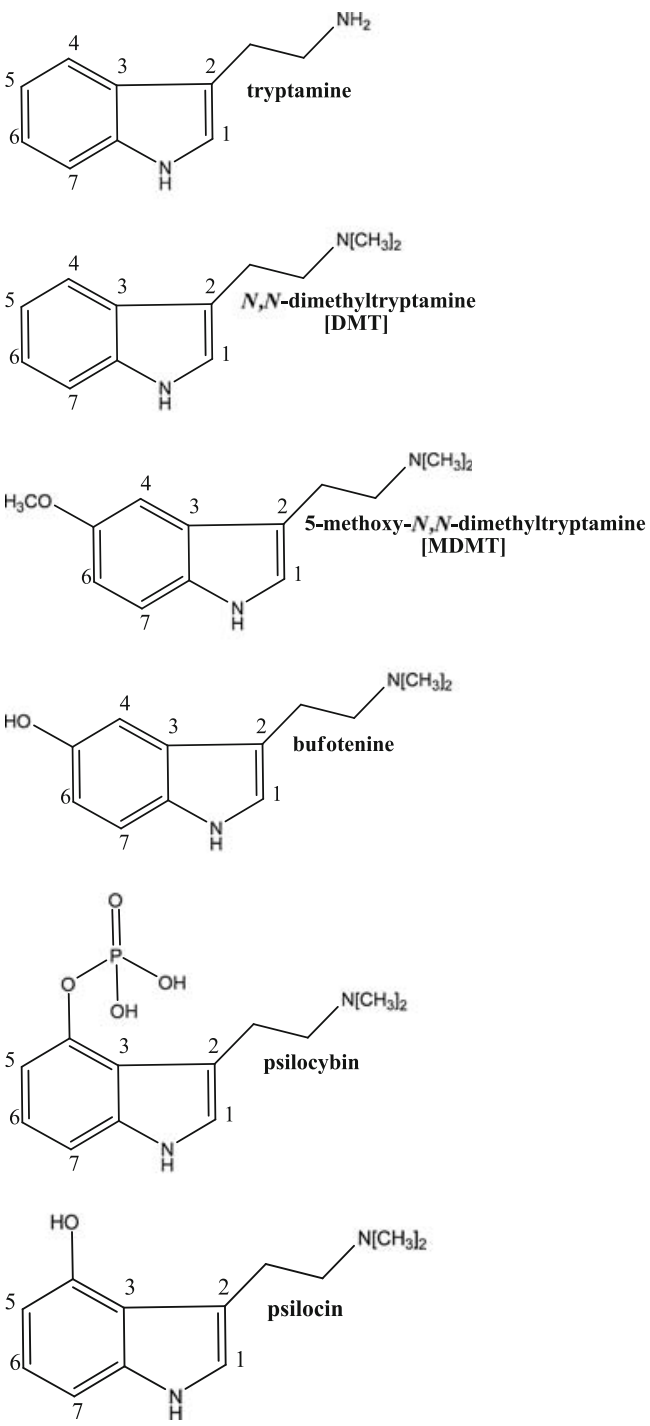

Fig. 2 Structures of tryptamine, bufotenine, and hallucinogenic tryptamines

(Gaddum 1953, 1957; Wooley and Shaw 1954) and (b) that the clinical syndromes produced by mescaline and DOM are quite similar to those following LSD and DMT (Hoch et al. 1952; Hollister et al. 1969a, b). That LSD, tryptamines, and phenethylamine hallucinogens might have a common mechanism was suggested by a number of observations. In human subjects (Balistrieri and Fontanari 1959; Wolbach et al. 1962b) as well as in animals (Appel and Friedman 1968; Winter 1971), cross-tolerance develops between LSD and mescaline. Furthermore, it was known that serotonergic antagonists block some of the nonbehavioral effects of phenethylamine hallucinogens in animals (Cheng et al. 1973; Horita et al. 1972). With respect to the stimulus effects of phenethylamine hallucinogens, antagonism of mescaline-induced stimulus control by the nonselective serotonergic antagonists was reported [LSD] 

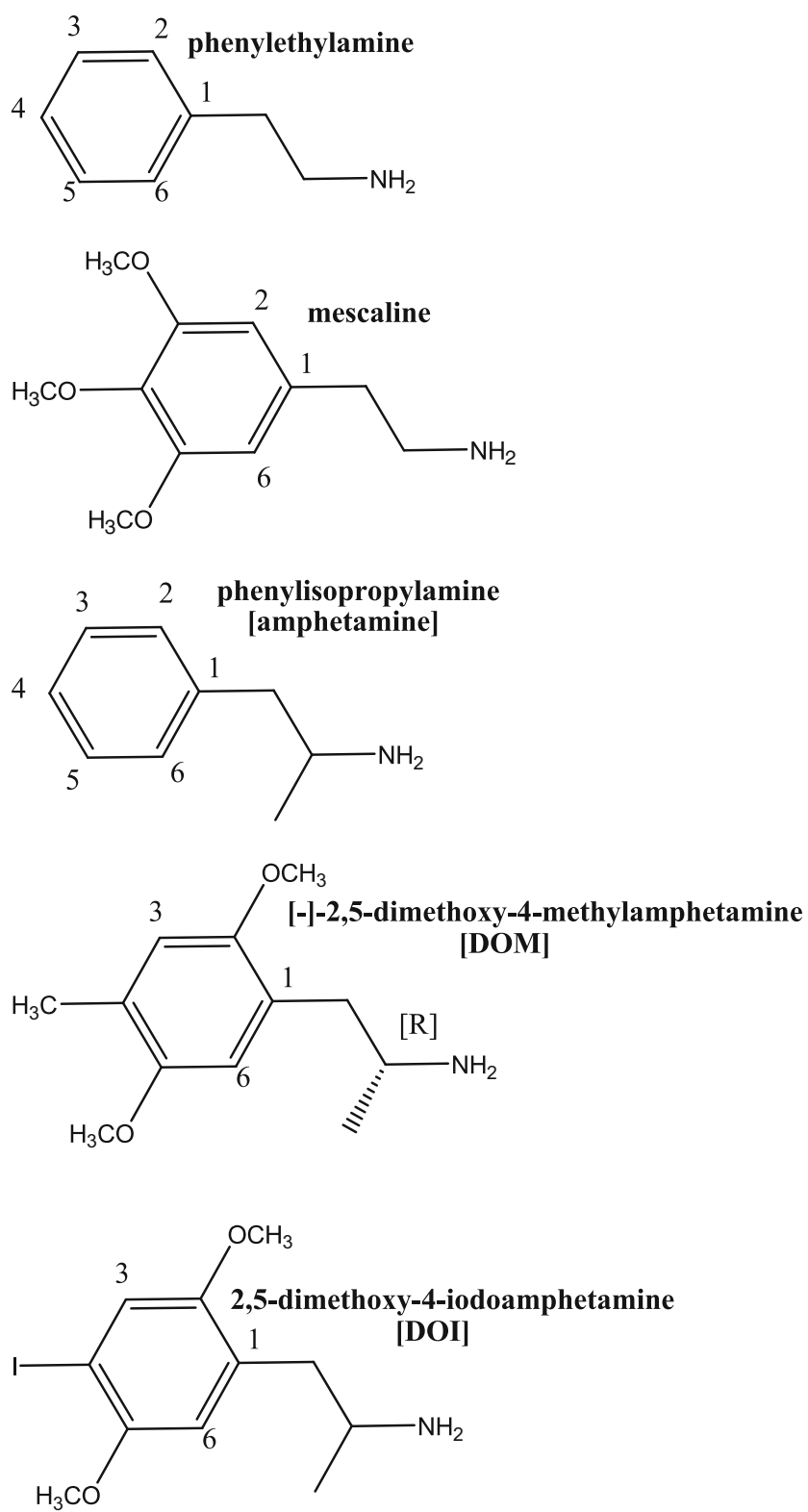

Fig. 3 Structures of phenethylamine and amphetamine together with ring-substituted hallucinogenic derivatives

independently by Browne and Ho (1975) and by Winter (1975). This observation was then extended to include other antagonists of serotonin and other hallucinogens including LSD (Kuhn et al. 1978), DOM (Winter 1978), and DMT (Young et al. 1982). It thus appeared appropriate to apply the term "serotonergic hallucinogen" to these structurally disparate drugs.

Two factors complicated this simple picture; the second of these was yet to appear but the first was evident at the time. The antagonists then available, drugs such as cinanserin, methysergide, cyproheptadine, mianserin, and pizotyline (BC-105), were nonselective with respect to other neurotransmitter systems and, indeed, some had behaviorally evident partial agonist effects in LSD-trained rats (Colpaert et al. 1982). Even the wonderfully efficacious LSD antagonist, pirenperone (Colpaert et al. 1982), was soon shown to have activity as a dopamine $D_{2}$ receptor antagonist (Meltzer et al. 1983).

The factor yet to be discovered was the complexity of the serotonergic family of drug receptors. The original classification by Gaddum and Picarelli (1957) of serotonin receptors as either $\mathrm{M}$ or $\mathrm{D}$, those blocked by morphine and by dibenzyline, respectively, was based on studies in smooth muscle and is now largely forgotten. In contrast, the two subtypes designated $5-\mathrm{HT}_{1}$ and $5-\mathrm{HT}_{2}$ by Peroutka and Snyder (1979) remain with us today but in a refined and expanded state that now includes 14 serotonin receptors categorized into seven families $\left(5-\mathrm{HT}_{1-7}\right.$; Nichols and Nichols 2008). Glennon et al. (1983, 1984) implicated the $5-\mathrm{HT}_{2}$ receptor in hallucinogenesis based upon a high degree of correlation between affinities for the $5-\mathrm{HT}_{2}$ receptor and both potency in substituting for DOM-induced stimulus control as well as hallucinogenic potency in man. However, the subsequent discovery of the $5-\mathrm{HT}_{2 \mathrm{C}}$ receptor (Pazos et al. 1984) with a high level of structural and functional similarities to the $5-\mathrm{HT}_{2 \mathrm{~A}}$ receptor as well as the demonstration that indoleamine and phenethylamine hallucinogens are partial agonists at the $5-\mathrm{HT}_{2 \mathrm{C}}$ receptor (Sanders-Bush et al. 1988; Burris et al. 1991) demanded consideration of this serotonin receptor subtype. Fiorella et al. (1995a) employed antagonist correlation analysis to address the question of the relative roles of the $5-\mathrm{HT}_{2 \mathrm{~A}}$ and the $5-\mathrm{HT}_{2 \mathrm{C}}$ receptors in stimulus control mediated by LSD and DOM. A series of ten serotonergic antagonists nonselective for the $5-\mathrm{HT}_{2 \mathrm{~A}}$ and the $5-\mathrm{HT}_{2 \mathrm{C}}$ receptors but with differing selectivity ratios for those receptors was used to block LSD-induced stimulus control and the generalization of LSD to DOM. The conclusion from this study was that stimulus control by LSD and the generalization of LSD to $\mathrm{DOM}$ are mediated by $5-\mathrm{HT}_{2 \mathrm{~A}}$ receptors. More direct evidence was provided by the antagonism of DOM-induced stimulus control by a newly discovered antagonist, AMI193, having 2,000-fold selectivity for the $5-\mathrm{HT}_{2 \mathrm{~A}}$ receptor as compared with the 5-HT $2 \mathrm{C}$ receptor (Ismaiel et al. 1993). However, like pirenperone before it, AMI-193 was found to have functionally significant activity as a dopamine $D_{2}$ antagonist (Czoty and Howell 2000). The current consensus is that differentiation of stimulus effects mediated by 5 $\mathrm{HT}_{2 \mathrm{~A}}$ and $5-\mathrm{HT}_{2 \mathrm{C}}$ receptors, respectively, is best accomplished with M100907 (MDL 100,907), a drug initially reported by Kehne et al. (1996) to have a potency ratio of 102 for binding affinity at $5-\mathrm{HT}_{2 \mathrm{~A}} / 5-\mathrm{HT}_{2 \mathrm{C}}$ receptors, a selectivity ratio of 1,283 for antagonism of 5-HT-stimulated inositol phosphate accumulation in NIH 3 T3 fibroblast cells expressing $5-\mathrm{HT}_{2 \mathrm{~A}}$ or $5-\mathrm{HT}_{2 \mathrm{C}}$ receptors, and a potency ratio 
of 2,647 for binding affinity at $5-\mathrm{HT}_{2 \mathrm{~A}} / \mathrm{DA} \mathrm{D}_{2}$ receptors. Subsequent studies employing a variety of receptor sources and competing ligands have yielded selectivity ratios ranging from 16 (Knight et al. 2004) to 186 (Schreiber et al. 1995; PDSP 2008). Despite the relatively low selectivity value found by Knight et al. (2004) using cloned human $5-\mathrm{HT}_{2 \mathrm{~A}}$ and $5-\mathrm{HT}_{2 \mathrm{C}}$ receptors and radiolabeled 2,5-dimethoxy-4-iodoamphetamine (DOI), M100907 was the most selective of 22 antagonists tested. The efficacy of M100907 as an antagonist of hallucinogen-induced stimulus control in the rat was first demonstrated by Schreiber et al. (1994) for DOI and has now been extended to include, among others, LSD, 5-MeO-DMT, and DOM. An interesting complication was added by Dekeyne et al. (2002, 2003) who observed that M100907 can establish stimulus control in the rat and suggested that the effect is mediated by antagonism of $5-\mathrm{HT}_{2 \mathrm{~A}}$ receptors with possible involvement of alpha $_{1}$ adrenoceptors and other yet to be identified mechanisms.

Despite the considerable evidence pointing to the 5$\mathrm{HT}_{2 \mathrm{~A}}$ receptor as the primary site mediating the stimulus effects of LSD and the phenethylamine hallucinogens, other serotonergic receptor subtypes almost certainly play at least a modulatory role (Darmani et al. 1990). Prominent among these are the $5-\mathrm{HT}_{1 \mathrm{~A}}$ receptor as well as the aforementioned $5-\mathrm{HT}_{2 \mathrm{C}}$ receptor. With respect to the latter receptor, Fiorella et al. (1995b) observed that potentiation of the stimulus effects of LSD caused by serotonin depletion (White et al. 1980) was accompanied by the upregulation of the $5-\mathrm{HT}_{2 \mathrm{C}}$ receptor. In addition, potentiation of the stimulus effects in rats of DOM and LSD by NMDA antagonists appears to involve a significant $5-\mathrm{HT}_{2 \mathrm{C}}$-receptor-mediated component (Eckler et al. 2004; Winter et al. 2005b). Although not directly related to hallucinogenesis, it is of interest that Cunningham and her colleagues (Filip and Cunningham 2003; Filip et al. 2006; Bubar and Cunningham 2006) have presented data in support of a modulatory role for the 5$\mathrm{HT}_{2 \mathrm{C}}$ receptor in the discriminative stimulus effects of cocaine.

Evidence implicating activity at the $5-\mathrm{HT}_{1 \mathrm{~A}}$ receptor as a mediator of stimulus control by the tryptaminergic hallucinogen, 5-MeO-DMT, will be discussed in somewhat greater detail below. With respect to the $5-\mathrm{HT}_{1 \mathrm{~A}}$ receptor as a modulating factor in stimulus control by hallucinogens, the data are both extensive and contradictory. In a study of membrane excitability of pyramidal neurons in rat cortex, it was found that the 5-HT 1 A agonist, 8-OH-DPAT, and the 5$\mathrm{HT}_{2 \mathrm{~A} / \mathrm{C}}$ agonist, (-)-2,5-dimethoxy-4-bromo-amphetamine (DOB), have opposite effects thus suggesting the hypothesis that activation of $5-\mathrm{HT}_{1 \mathrm{~A}}$ and $5-\mathrm{HT}_{2}$ receptors have opposing effects (Araneda and Andrade 1991). Behavioral data in support of these results include antagonism by $5-\mathrm{HT}_{1 \mathrm{~A}}$ agonists of DOI-induced head twitch (Arnt and
Hyttel 1989; Schreiber et al. 1995; Darmani et al. 1990) and wet dog shakes (Willins and Meltzer 1997) in the rat, effects widely accepted as indicative of agonist activity at $5-\mathrm{HT}_{2 \mathrm{~A}}$ receptors. In a study of stimulus control in the rat by the $5-\mathrm{HT}_{1 \mathrm{~A}}$ agonist, flesinoxan, it likewise was concluded that $5-\mathrm{HT}_{1 \mathrm{~A}}$ receptor activation has an inhibitory effect on activation of $5-\mathrm{HT}_{2 \mathrm{~A}}$ receptors (Herremans et al. 1999). Against this background, it is difficult to reconcile the observation that DOM-induced stimulus control is potentiated by 8-OH-DPAT (Glennon 1991). Furthermore, LSD-induced stimulus control was found by Reissig et al. (2005) to be potentiated by 8-OH-DPAT as well as by the $5-\mathrm{HT}_{1 \mathrm{~A}}$ receptor agonists, buspirone, gepirone, and ipsapirone. The potentiating effects of these agents were completely antagonized by the $5-\mathrm{HT}_{1 \mathrm{~A} / 7}$ receptor-selective antagonist, WAY-100,635. It is clear that further studies will be needed to resolve apparent inconsistencies.

Dopamine Despite the abundant evidence of a primary role for serotonergic mechanisms in the actions of indoleamine and phenethylamine hallucinogens and the emerging evidence for glutamatergic factors, note must also be taken of dopamine and possible serotonergic-dopaminergicglutamatergic interactions. On the basis of drug discrimination data in the rat, Marona-Lewicka and Nichols (2007) have proposed that stimulus control by LSD occurs in two phases, the first mediated by serotonin and a second later phase mediated by dopamine, and that this dopaminergic component is not shared by phenethylamine or tryptamine hallucinogens (Marona-Lewicka et al. 2005). The same group (Marona-Lewicka et al. 2008) subsequently suggested a primary role for the dopamine $\mathrm{D}_{4}$ receptor. It should be noted however that, in a study in human subjects, the dopamine $\mathrm{D}_{2}$ antagonist, haloperidol, significantly altered some of the subjective effects of psilocybin (Vollenweider et al. 1998a). Furthermore, psilocybin reduced $\left[{ }^{11} \mathrm{C}\right]$ raclopride binding potential as measured by positron emission tomography (Vollenweider et al. 1999). In the latter study, the authors concluded that this effect must be indirect in nature, citing a 1975 report that psilocin has only negligible affinity for dopamine receptors (Creese et al. 1975). However, in light of the provocative data presented by the Nichols group, our present knowledge of multiple dopamine receptor subtypes, the continued discovery of more selective dopaminergic ligands, and renewed interest in hallucinogens as tools for the understanding of psychosis, this issue clearly is worthy of further investigation.

Glutamate In considering hallucinogens as psychotomimetics, clear distinctions have been drawn between noncompetitive antagonists at the NMDA subtype of 
glutamate receptor and serotonergic hallucinogens. The respective subjective effects of glutamatergics and serotonergics in human subjects are quite different (Luby et al. 1959; Hofmann 1959; Carroll 1990) and their presumed mechanisms are distinct (Koek 1999; Winter et al. 2000a). Recently, however, there has been an increasing recognition that these systems do not operate in isolation but, instead, that there are complex and ever changing interactions between them. Illustrative of such interactions is the observation of potentiation of the stimulus effects in rats of DOM and LSD by ketamine, dizocilpine, and PCP (Winter et al. 2000a, 2004). An explanation for such interactions is provided by the hypothesis that glutamate release represents a final common pathway for the actions both of serotonergic and of glutamatergic hallucinogens (Aghajanian and Marek 1999, 2000). Though the mechanisms of these interactions are largely unknown, there is evidence that the NMDA antagonists do not act directly upon 5- $\mathrm{HT}_{2 \mathrm{~A}}$ receptors (Rabin et al. 2000) and that the $5-\mathrm{HT}_{2 \mathrm{C}}$ receptor may play a significant role (Eckler et al. 2004; Winter et al. 2005b). Direct testing of the hypothesis that glutamate release is correlated with behavioral effects of both serotonergics and glutamatergics has been greatly aided by the discovery of a family of ligands for group II (mGlu2/3) metabotropic glutamate receptors. These agents, exemplified by the antagonist LY341495 and the agonist LY379268, are able to increase and to decrease, respectively, glutamate release in vivo. It was observed in rats trained with LSD as a discriminative stimulus that LY379268 produced significant, albeit intermediate, antagonism of LSD-induced stimulus control and that LY341495 resulted in potentiation of the stimulus effects of LSD (Winter et al. 2004). These results provide significant behavioral support for the hypothesis of Aghajanian and Marek (1999) that hallucinogenesis is glutamatergically mediated. It remains to be seen whether the interactions observed between LSD and the metabotropic glutamatergic ligands generalize to the tryptamine and phenethylamine hallucinogens. Were these matters not already sufficiently complex, Benneyworth et al. (2008) have reported that chronic treatment in a drug discrimination study with the phenethylamine hallucinogen, DOB, attenuates the behavioral effects of the mGlu2/3 receptor agonist, LY379268. This finding has implications for all investigations of the stimulus effects of drugs and, perhaps, may explain differences noted when results from discrimination studies are compared with dependent variables requiring only acute treatment. With respect to possible links between glutamate, hallucinogens, and psychosis, it is most interesting that an agonist at $\mathrm{mGlu} 2 / 3$ receptors has been found to be efficacious in the treatment of schizophrenia (Patil et al. 2007).

\section{Tryptamine hallucinogens}

5-methoxy-N,N-dimethyltrypamine Against the background provided above implicating the $5-\mathrm{HT}_{2 \mathrm{~A}}$ receptor as the primary site of action of LSD and the phenethylamine hallucinogens and the $5-\mathrm{HT}_{2 \mathrm{C}}$ receptor as a significant modulatory site, the tryptamine hallucinogens are puzzling. In terms of stimulus generalization, there is no absence in the literature of reports that the tryptamine hallucinogens mimic LSD and the phenethylamines and vice versa. Nonetheless, there have been repeated intimations that the pattern of antagonism of the tryptamines may differ from that of LSD (Young et al. 1982, 1983, 1986). Later suggestions focus on the $5-\mathrm{HT}_{1 \mathrm{~A}}$ receptor (Marona-Lewicka and Nichols 1995). In a particularly interesting study, Blair et al. (2000) reported that ring fluorination of hallucinogenic tryptamines reduced the degree of mimicry of the stimulus effects of LSD by these drugs while at the same time diminishing their affinity for the $5-\mathrm{HT}_{1 \mathrm{~A}}$ receptor. The tryptamines, ranging from classic agents such as DMT (Sai-Halasz et al. 1958) to a series of ring- and amine-substituted agents such as DPT (Fantegrossi et al. 2008b; Li et al. 2008), 2,5-dimethoxy4-n-propylthiophenethylamine (Fantegrossi et al. 2005), and 5-methoxy- $N, N$-diisopropyltryptamine (Fantegrossi et al. 2006), are unquestionably hallucinogenic (Shulgin and Shulgin 1997) yet binding data regularly indicate that their highest affinity is for $5-\mathrm{HT}_{1 \mathrm{~A}}$ receptors. Indeed, a study by Spencer et al. (1987) concluded that stimulus control by 5 $\mathrm{MeO}-\mathrm{DMT}$ in the rat is mediated by $5-\mathrm{HT}_{1 \mathrm{~A}}$ receptors. This conclusion was fully supported by a subsequent investigation (Winter et al. 2000b) that employed WAY100,635 , an agent not yet discovered at the time of the work by Spencer et al. The latter study suggested as well that 5-MeO-DMT differs from LSD and DOM with respect to the serotonergic element which mediates stimulus control in the rat but that it shares with those drugs a functionally significant interaction with $5-\mathrm{HT}_{2}$ receptors. In support of this hypothesis, 5-MeO-DMT as well as the closely related analog, DMT, displays partial agonist activity at the 5- $\mathrm{HT}_{2 \mathrm{~A}}$ receptor expressed in PC125- $\mathrm{HT}_{2 \mathrm{~A}}$ cells (Rabin et al. 2002). Left unanswered at this time is the question of whether activity at the $5-\mathrm{HT}_{1 \mathrm{~A}}$ receptor plays a functionally significant role in hallucinogenesis by the tryptamines.

Psilocybin In reports of drug-induced stimulus control, psilocybin has been found to substitute fully for racemic DOM (Silverman and Ho 1980) and mescaline (Appel and Callahan 1989) thus suggesting a $5-\mathrm{HT}_{2}$-mediated effect because phenethylamines such as DOM (Pauwels et al. 1993 ) and, presumably, mescaline have negligible affinity for $5-\mathrm{HT}_{1 \mathrm{~A}}$ receptors. Furthermore, Vollenweider et al. 
(1996) observed that the subjective effects in normal subjects of psilocybin are blocked by ketanserin (Vollenweider et al. 1996, 1998a), an antagonist with low nanomolar affinity for 5- $\mathrm{HT}_{2 \mathrm{~A}}$ receptors (Richelson and Souder 2000) and only micromolar affinity for $5-\mathrm{HT}_{1 \mathrm{~A}}$ receptors (Boess and Martin 1994). Receptor binding data provided no clue in that Blair et al. (2000) observed $K_{I}$ values for psilocin of 49,25 , and $10 \mathrm{nM}$ for $5-\mathrm{HT}_{1 \mathrm{~A}}, 5-\mathrm{HT}_{2 \mathrm{~A}}$, and $5-\mathrm{HT}_{2 \mathrm{C}}$ receptors, respectively. Nonetheless, given the close structural similarity of 5MeO-DMT and both psilocybin and psilocin (Fig. 2), it was expected that psilocybin-induced stimulus control in the rat would have a salient element mediated by agonist activity at the $5-\mathrm{HT}_{1 \mathrm{~A}}$ receptor. That expectation was not realized (Winter et al. 2007). Instead, it was found that, while the full generalization of psilocybin to LSD and DOM is completely blocked by M100907, psilocybin itself is only partially antagonized. Most remarkable, psilocybin-induced stimulus control was diminished not at all by WAY-100,635. It appears that there remains much to be learned regarding the tryptamine family of hallucinogens and, in particular, the functional effects of ligands at $5-\mathrm{HT}_{1 \mathrm{~A}}$ receptors. Our fascination with these drugs is further heightened by the continued interest in the human pharmacology of DMT (Strassman 1991) and a possible role for bufotenine as an endogenous psychotogen (RJ Strassman, personal communication). That the $5-\mathrm{HT}_{1 \mathrm{~A}}$ receptor might provide a link between the serotonergic and glutamatergic systems is suggested by the emergence of aripiprazole, an atypical antipsychotic with agonist activity at $5-\mathrm{HT}_{1 \mathrm{~A}}$ receptors (Bortolozzi et al. 2007); PCP-induced deficits in social interaction and recognition memory in rats are ameliorated by aripiprazole and these effects of aripiprazole are antagonized by WAY-100,635 (Bruins Slot et al. 2005; Snigdha and Neill 2008; Nagai et al. 2008).

Species differences The majority of studies of stimulus control by hallucinogens have been done in the rat, most often employing a two-lever choice procedure. This uniformity has the virtue of making much of the literature directly comparable. On the other hand, possible species differences are obscured. Unfortunately, there is little to be said about possible differences between the rat and primates, whether monkey or man, for the simple reason that few studies have been conducted in the latter species. Indeed, I am aware of only two investigations which employed infrahuman primates. Nielson (1985) trained four monkeys (Cercopithecus aethiops) with LSD and Li et al. (2008) established DOM as a discriminative stimulus in four rhesus monkeys. Given this paucity, one cannot draw broad conclusions but it is of interest that while the data of $\mathrm{Li}$ et al. for DOM are consistent with findings in the rat, e.g., complete antagonism by M100907, Nielsen observed a maximum of $55 \%$ antagonism of LSD by pirenperone and no blockade by pizotyline, results clearly at odds with the rat literature. In the only study in which rats and monkeys were compared directly, Jones et al. (1998) observed approximately $50 \%$ generalization of PCP to LSD in rats but no consistent evidence of generalization in the four monkeys tested. Turning to human subjects, the stimulus effects of a number of psychoactive drugs have been well characterized (for reviews, see Chait et al. 1984; Kamien et al. 1993; Brauer et al. 1997; Dykstra et al. 1997) but, to my knowledge, there have been no reports of the training or cross testing of LSD or any of the tryptamine-phenethylamine hallucinogens. It should be noted that methylenedioxymethamphetamine (MDMA, Ecstasy), a drug sometimes said to be hallucinogenic, has been examined in human subjects trained to simultaneously discriminate $d$-amphetamine, metachlorophenylpiperazine, and placebo (Johanson et al. 2006). MDMA shared some effects with both reference drugs and all three increased scores on the hallucinogen rating scale (Strassman et al. 1994) but none of the participants reported hallucinations nor were hallucinations observed by Vollenweider et al. (1998b) despite some references to this paper to the contrary. While the consensus is that MDMA is not hallucinogenic, drug discrimination studies in animals indicate a number of interesting generalizations, almost always partial in nature, to hallucinogens and vice versa. The complexities of the animal data are well represented by the elegant work of Baker and her colleagues (Baker and Taylor 1997; Baker et al. 1995; Goodwin and Baker 2000; Goodwin et al. 2003) using both two- and three-choice tasks.

Beginning with the training of mice with amphetamine by Snoddy and Tessel (1983), this species has been used infrequently relative to the rat. Nevertheless, a number or other drugs have been examined including hallucinogens of the noncompetitive NMDA antagonist type, PCP (Middaugh et al. 1988; English et al. 1999) and dizocilpine (MK-801; Geter-Douglas and Witkin 1999). In the first report of stimulus control by a hallucinogen of the indole-phenethylamine type, Smith et al. (2003) employed racemic DOI (Shulgin and Shulgin 1991). This was followed soon after by reports of the training of LSD (Benneyworth et al. 2005; Winter et al. 2005a). Broadly speaking, the results were compatible with earlier studies in the rat. DOI generalized fully to LSD and to DOB and DOI-induced stimulus control was fully antagonized by M100907 (Smith et al. 2003). In LSD-trained mice, full generalization was observed to DOB (Benneyworth et al. 2005) and to DOM (Winter et al. 2005a). An unexpected finding in both studies of LSD was the absence of complete blockade of the stimulus effects of LSD by the selective $5-\mathrm{HT}_{2 \mathrm{~A}}$ selective antagonist, M100907, results clearly at odds with those in the rat. On the basis of partial antagonism by selective $5-\mathrm{HT}_{2 \mathrm{C}}$ receptor antagonists, 
Benneyworth et al. (2005) suggested a significant role for this receptor while Winter et al. (2005a) invoked the 5$\mathrm{HT}_{1 \mathrm{~A}}$ receptor in attempting to explain rate suppression following M100907 and the combination of the antagonist with LSD, effects not observed in the rat.

With the advent of techniques to genetically modify mice, this species provides the advantage that a particular gene can be deleted to produce knockout (KO) mice (Gingrich and Hen 2001; Bucan and Abel 2002; Seong et al. 2002). Although KO mice have been employed in investigations of the stimulus effects of nicotine (Stolerman et al. 2004), cocaine (Chausmer et al. 2002; Katz et al. 2003; Elliot et al. 2003), and ethanol (Shannon et al. 2004); until recently, there have been no studies of hallucinogens reported. In 2007, Krall et al. described an investigation in which the stimulus effects of LSD were examined in mice lacking the serotonin transporter (SERT; Bengel et al. 1998). Previous work had shown that the changes in SERT KO mice due to gene deletion are restricted almost exclusively to the serotonergic system including reduction in $5-\mathrm{HT}_{1 \mathrm{~A}}$ and $5-\mathrm{HT}_{2 \mathrm{~A}}$ receptors. Krall et al. (2007) observed that C57BL/6 mice homozygous for the null mutation $\left(\mathrm{SERT}^{-/-}\right)$were impaired in their ability to establish stimulus control with LSD as compared with littermate controls $\left(\mathrm{SERT}^{+/+}\right)$. Obvious experiments yet to be reported include the assessment of the stimulus effects of hallucinogens in mice in which $5-\mathrm{HT}_{2 \mathrm{~A}}, 5-\mathrm{HT}_{2 \mathrm{C}}$, and 5$\mathrm{HT}_{1 \mathrm{~A}}$ receptors, respectively, have been knocked out.

Compound stimuli Selective agonists and antagonists are among the most powerful tools for analyzing the stimulus effects of hallucinogens. Progress in establishing mechanisms of action of psychoactive drugs has been and continues to be dependent upon the discovery of ever more selective ligands. We are fortunate at this time to have available the 5- $\mathrm{HT}_{2 \mathrm{~A}}$ receptor antagonist, M100907 (Kehne et al. 1996), and the 5- $\mathrm{HT}_{1 \mathrm{~A} / 7}$ receptor antagonist, WAY100,635 (Gozlan et al. 1995). Many of the apparent contradictions found in the drug discrimination literature may be reconciled if we assume that a drug may function as a compound stimulus with each element mediated by a distinct pharmacological receptor. For example, according to the Berry-Ator hypothesis of specificity in drug discrimination, asymmetrical generalizations are explained in terms of differential salience of individual elements of the compound stimulus depending upon experimental factors including the training drug, the dose of that drug, etc. (Ator and Griffiths 1989). Given the fact that LSD binds with high affinity to a variety of receptors (Leysen 1985), it is a prime candidate to function as a compound stimulus. Figure 4 illustrates the use of M100907 and WAY100,635 to rationalize the effects of 8-OH-DPAT in rats trained with LSD as a discriminative stimulus. It is seen

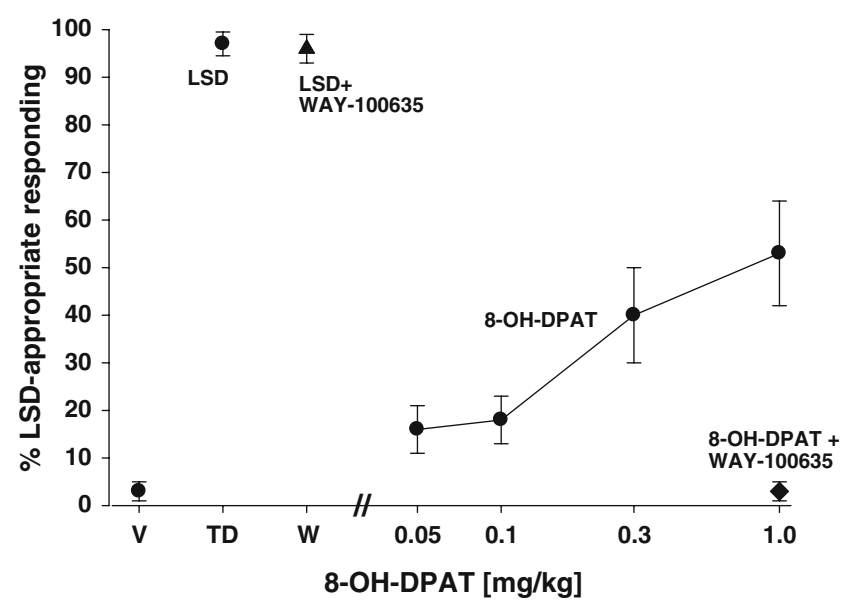

Fig. 4 Effects of a range of doses of 8-OH-DPAT alone and in combination with WAY-100,635 $(0.3 \mathrm{mg} / \mathrm{kg}, \mathrm{SC})$ in rats trained with LSD $(0.1 \mathrm{mg} / \mathrm{kg})$ as a discriminative stimulus. Each point represents the mean of 9-12 animals. The points at $V$ and $T D$ on the abscissa are for the saline and LSD training conditions, respectively. The point at $W$ on the abscissa is for the combination of the training dose of LSD and WAY-100,635 (redrawn from Reissig et al. 2005)

that the generalization of LSD to 8-OH-DPAT is intermediate in nature and that this intermediate generalization is completely antagonized by WAY-100,635. In contrast, stimulus control by LSD is influenced not at all by WAY100,635 . The conclusion to be drawn is that LSD does indeed induce a compound stimulus which includes elements mediated by both $5-\mathrm{HT}_{2 \mathrm{~A}}$ and $5-\mathrm{HT}_{1 \mathrm{~A}}$ receptors. The former element is witnessed by the complete antagonism of LSD-induced stimulus control by M100907 (Winter et al. 2004). The latter element is evident only when generalization of $\mathrm{LSD}$ to a $5-\mathrm{HT}_{1 \mathrm{~A}}$ receptor agonist is tested. A final note: we must remain aware of the sometimes-ephemeral nature of the title selective when applied to a drug. For example, with respect to WAY100,635 , agonist activity at the dopamine $\mathrm{D}_{4}$ receptor has been reported (Chemel et al. 2006; Marona-Lewicka et al. 2008). Nonetheless, Martel et al. (2007) express confidence in the selectivity of WAY-100,635 for the $5-\mathrm{HT}_{1 \mathrm{~A}}$ receptor as compared with the dopamine $\mathrm{D}_{4}$ receptor. As noted above, various estimates have been provided for the selectivity ratio of M100907 for the $5-\mathrm{HT}_{2 \mathrm{~A}}$ and $5-\mathrm{HT}_{2 \mathrm{C}}$ receptors, respectively. We can only hope that synthetic chemists will eventually provide uniquely selective agonists and antagonists at every receptor of interest to those who study stimulus control by hallucinogens.

Epilog During the 30-year life of the Society for Stimulus Properties of Drugs, study of stimulus control by hallucinogens in animals has come a long way from the time when an anonymous reviewer described results (Winter 1978) 
submitted to the Journal of Pharmacology and Experimental Therapeutics as having "a scent of the occult." Today, preclinical analysis of the stimulus effects of potentially psychoactive drugs has gained near universal acceptance. More important, in my opinion, are stimulus control studies that seek the still elusive mechanisms of action of hallucinogens. There remain of course those who question the relevance to the human condition of studies of hallucinogens in animals. Might hallucination be a uniquely human experience and, even if not, how are we to demonstrate, in the absence of verbal communication, the validity of an animal model of complex human behavior? My answer to those critics is that if we can agree that all translations of data from nonhuman species to predictions for man involve, to use Weinberg's term (1972), a transscientific residue, then our task in studying the stimulus effects in animals of hallucinogens and other drugs whose actions in man include a prominent subjective component is to make predictions for man which are amenable to clinical verification. In the wise words of Lawrence Berra, "it's tough to make predictions, especially about the future." Nonetheless, if the rebirth of human studies of hallucinogens is at hand (Doblin 2002; Morris 2008), we may envisage a time when close relationships exist between those who study hallucinogens in man and in animals, a time when hypotheses based on animal data are quickly confirmed, or rejected, in the clinical laboratory.

Acknowledgements Support for studies in my laboratory initially was provided by the National Institute on Mental Health and, soon after its creation, by the National Institute on Drug Abuse. My thanks to Peter Gessner, who first stimulated my interest in hallucinogens, and to those who fostered my education in drug-induced stimulus control. That education began with Victor Laties and Bernard Weiss and was aided immeasurably by those who have passed through my laboratory, the work of many of whom is cited in this review. My collaboration with Richard Rabin, who for several decades has provided the biochemical correlates of our behavioral studies, is much appreciated. Finally, I thank Katherine Bonson, Anne Dekeyne, Mireille Doat-Meyerhoefer, and Jessica Winter for their critical comments on an earlier version of this paper.

\section{References}

Aghajanian GK, Marek GJ (1999) Serotonin and hallucinogens. Neuropsychopharmacology 21:16S-23S

Aghajanian GK, Marek GJ (2000) Serotonin model of schizophrenia: emerging role of glutamate mechanisms. Brain Res Rev 31:302-312

Alles GA (1959) Some relations between chemical structure and physiological action of mescaline and related compounds. In: Abramson HA (ed) Neuropharmacology. Madison, Madison, NJ, USA

Appel JB, Callahan PM (1989) Involvement of 5-HT receptor subtypes in the discriminative stimulus properties of mescaline. Eur J Pharmacol 159:41-46
Appel JB, Freedman DX (1968) Tolerance and cross-tolerance among psychotomimetic drugs. Psychopharmacologia 13:267-274

Appel JB, White FJ, Holohean AM (1982) Analyzing mechanisms of hallucinogenic drug action with drug discrimination procedures. Neurosci Biobehav Rev 6:529-536

Araneda R, Andrade R (1991) 5-Hydroxytryptamine2 and 5hydroxytryptamine $1 \mathrm{~A}$ receptors mediate opposing responses on membrane excitability in rat association cortex. Neuroscience 40:399-412

Arnt J, Hyttel J (1989) Facilitation of 8-OH-DPAT-induced forepaw treading of rats by the $5-\mathrm{HT}_{2}$ agonist DOI. Eur J Pharmacol $161: 45-51$

Ator NA, Griffiths RR (1989) Asymmetrical cross-generalization in drug discrimination with lorazepam and pentobarbital training conditions. Drug Dev Res 16:355-364

Baker LE, Taylor MM (1997) Assessment of the MDA and MDMA optical isomers in a stimulant-hallucinogen discrimination. Pharmacol Biochem Behav 57:737-748

Baker LE, Broadbent J, Michael EK, Matthews PK, Metosh CA, Saunders RB, West WB, Appel JB (1995) Assessment of the discriminative stimulus effects of the optical isomers of ecstasy (3,4-methylenedioxymethamphetamine; MDMA). Behav Pharmacol 6:263-275

Balestrieri A, Fontanari D (1959) Acquired and crossed tolerance to mescaline, LSD-25, and BOL-148. Arch Gen Psychiatry $1: 279-282$

Bengel D, Murphy DL, Andrews AM, Wichems CH, Feltner D, Heils A, Mossner R, Westphal H, Lesch KP (1998) Altered brain serotonin homeostasis and locomotor sensitivity to MDMA ["Ecstasy"] in serotonin transporter-deficient mice. Mol Pharmacol 53:649-655

Benneyworth MA, Smith RL, Barrett RJ, Sanders-Bush E (2005) Complex discriminative stimulus properties of $[+]$ lysergic acid diethylamide [LSD] in C57B1/6J mice. Psychopharmacology 179:854-862

Benneyworth MA, Smith RL, Sanders-Bush E (2008) Chronic phenethylamine hallucinogen treatment alters behavioral sensitivity to a metabotropic glutamate $2 / 3$ receptor agonist. Neuropsychopharmacology 33:2206-2216

Blair JB, Kurrasch-Orbaugh D, Marona-Lewicka D, Cumbay MG, Watts VJ, Barker EL, Nichols DE (2000) Effect of ring fluorination on the pharmacology of hallucinogenic tryptamines. J Med Chem 43:4701-4710

Boess FG, Martin IL (1994) Molecular biology of 5-HT receptors. Neuropharmacology 33:275-317

Bortolozzi A, Díaz-Mataix L, Toth M, Celada P, Artigas F (2007) In vivo actions of aripiprazole on serotonergic and dopaminergic systems in rodent brain. Psychopharmacology 191:745-758

Brauer LH, Goudie AJ, deWit H (1997) Dopamine ligands and the stimulus effects of amphetamine: animal models versus human laboratory data. Psychopharmacology 130:2-13

Browne RG, Ho BT (1975) Role of serotonin in the discriminative stimulus properties of mescaline. Pharmacol Biochem Behav 3:429-435

Bruins Slot LA, Kleven MS, Newman-Tancredi A (2005) Effects of novel antipsychotics with mixed $\mathrm{D}(2)$ antagonist/5-HT(1A) agonist properties on PCP-induced social interaction deficits in the rat. Neuropharmacology 49:996-1006

Bubar MJ, Cunningham KA (2006) Serotonin 5-HT2A and 5-HT2C receptors as potential targets for modulation of psychostimulant use and dependence. Curr Top Med Chem 6:1971-1985

Bucan M, Abel T (2002) The mouse: genetics meets behavior. Nat Rev Genet 3:114-123

Burris KD, Breeding M, Sanders-Bush E (1991) (+)Lysergic acid diethylamide, but not its nonhallucinogenic congeners, is a potent serotonin 5HT1C receptor agonist. J Pharmacol Exp Ther 258:891-896 
Carroll ME (1990) PCP and hallucinogens. Adv Alcohol Subst Abuse 9:167-190

Chait LD, Uhlenhuth EH, Johanson C (1984) An experimental paradigm for studying the discriminative stimulus properties of drugs in humans. Psychopharmacology 82:272-274

Chausmer AL, Elmer GI, Rubinstein M, Low MJ, Grandy DK, Katz JL (2002) Cocaine-induced locomotor activity and cocaine discrimination in dopamine D2 receptor mutant mice. Psychopharmacology 163:54-61

Chemel BR, Roth BL, Armbruster B, Watts VJ, Nichols DE (2006) WAY-100635 is a potent dopamine D4 receptor agonist. Psychopharmacology 188:244-251

Cheng HC, Long JP, Barfknecht CF, Nichols DE (1973) Cardiovascular effects of 2,5-dimethoxy-4-methylamphetamine (DOM, STP). J Pharmacol Exp Ther 186:345-354

Colpaert FC, Niemegeers CJ, Janssen PA (1982) A drug discrimination analysis of lysergic acid diethylamide (LSD): in vivo agonist and antagonist effects of purported 5-hydroxytryptamine antagonists and of pirenperone, a LSD-antagonist. J Pharmacol Exp Ther 221:206-214

Corne SJ, Pickering RW (1967) A possible correlation between druginduced hallucinations in man and a behavioural response in mice. Psychopharmacologia 11:65-78

Creese I, Burt DR, Snyder SH (1975) The dopamine receptor differential binding of d-LSD and related agents to agonist and antagonist states. Life Sci 17:1715-1719

Czoty PW, Howell LL (2000) Behavioral effects of AMI-193, a 5$\mathrm{HT}_{2 \mathrm{~A}}$-and dopamine D2-receptor antagonist, in the squirrel monkey. Pharmacol Biochem Behav 67:257-264

Darmani NA, Martin BR, Pandey U, Glennon RA (1990) Do functional relationships exist between 5-HT1A and 5-HT2 receptors. Pharmacol Biochem Behav 36:901-906

DeKeyne A, Iob L, Hautefaye P, Millan MJ (2002) The selective serotonin 2A receptor antagonist, MDL100,907, elicits a specific interoceptive cue in rats. Neuropsychopharmacology 26:552-556

DeKeyne A, Iob L, Millan MJ (2003) Generalization of clozapine to other antipsychotic agents in a discriminative stimulus elicited by the serotonin 2A antagonist, MDL100,907. Neuropharmacology 44:604-615

Dixon AK (1968) Evidence of catecholamine mediation in the "aberrant" behavior induced by lysergic acid diethylamide (LSD) in the rat. Experientia 24:743-747

Doblin R (2002) A clinical plan for MDMA [Ecstasy] in the treatment of posttraumatic stress disorder [PTSD]: partnering with the FDA. J Psychoactive Drugs 34:185-194

Dykstra LA, Preston KL, Bigelow GE (1997) Discriminative stimulus and subjective effects of opioids with mu and kappa activity: data from laboratory animals and human subjects. Psychopharmacology 130:14-27

Eckler JR, Reissig CJ, Rabin RA, Winter JC (2004) A 5-HT 2 C receptormediated interaction between 2,5-dimethoxy-4-methylamphetamine [DOM] and citalopram in the rat. Pharmacol Biochem Behav 79:25-30

Elliot EE, Sibley DR, Katz JL (2003) Locomotor and discriminative stimulus effects of cocaine in dopamine $\mathrm{D}_{5}$ receptor knockout mice. Psychopharmacology 169:161-168

English JA, Bruce KH, Paul IA (1999) Increased discriminative stimulus potency of PCP in C57BL/6 mice infected with the LPBM5 retrovirus. Eur J Pharmacol 367:1-5

Fantegrossi WE, Harrington AW, Eckler JR, Rabin RA, Winter JC, Coop A, Rice KR, Woods JH (2005) Hallucinogen-like actions of 2,5-dimethoxy-4-n-propylthiophenethylamine [2C-T-7] in mice and rats. Psychopharmacology 181:496-503

Fantegrossi WE, Harrington AW, Kiessel CL, Eckler JR, Rabin RA, Winter JC, Coop A, Rice KC, Woods JH (2006) Hallucinogen- like actions of 5-methoxy- $N, N$-diisopropyltryptamine in mice and rats. Pharmacol Biochem Behav 83:122-129

Fantegrossi WE, Murnane KS, Reissig CJ (2008a) The behavioral pharmacology of hallucinogens. Biochem Pharmacol 75:17-33

Fantegrossi WE, Reissig CJ, Katz EB, Yarosh HL, Rice KC, Winter JC (2008b) Hallucinogen-like effects of $N, N$-dipropyltryptamine [DPT]: possible mediation by $5-\mathrm{HT}_{1 \mathrm{~A}}$ and $5-\mathrm{HT}_{2 \mathrm{~A}}$ receptors in rodents. Pharmacol Biochem Behav 88:358-365

Filip M, Cunningham KA (2003) Hyperlocomotive and discriminative stimulus effects of cocaine are under the control of serotonin2C (5-HT2C) receptors in rat prefrontal cortex. J Pharmacol Exp Ther 306:734-743

Filip M, Bubar MJ, Cunningham KA (2006) Contribution of serotonin (5-HT) 5-HT2 receptor subtypes to the discriminative stimulus effects of cocaine in rats. Psychopharmacology 183:482-489

Fiorella D, Rabin RA, Winter JC (1995a) The role of the 5-HT $2 \mathrm{~A}$ and $5-\mathrm{HT}_{2 \mathrm{C}}$ receptors in the stimulus effects of hallucinogenic drugs I: antagonist correlation analysis. Psychopharmacology 121:347-356

Fiorella D, Helsley SE, Lorrain DS, Palumbo PA, Rabin RA, Winter JC (1995b) The role of the $5-\mathrm{HT}_{2 \mathrm{~A}}$ and $5-\mathrm{HT}_{2 \mathrm{C}}$ receptors in the stimulus effects of hallucinogenic drugs III: the mechanistic basis for supersensitivity to the LSD stimulus following serotonin depletion. Psychopharmacology 121:364-372

Gaddum J (1953) Antagonism between lysergic acid diethylamide and 5-hydroxytryptamine. J Physiol 121:15P

Gaddum JH (1957) Serotonin-LSD interactions. Ann NY Acad Sci 14:643-647

Gaddum JH, Picarelli ZP (1957) Two kinds of tryptamine receptor. Br J Pharmacol 120(Suppl):134-139

Geter-Douglas B, Witkin JM (1999) Behavioral effects and anticonvulsant efficacies of low-affinity, uncompetitive NMDA antagonists in mice. Psychopharmacology 146:280-289

Gingrich JA, Hen R (2001) Dissecting the role of the serotonin system in neuropsychiatric disorders using knockout mice. Psychopharmacology 155:1-10

Glennon RA (1991) Discriminative stimulus properties of hallucinogens and related designer drugs. In: Glennon RA, Jarbe TUC, Frankenheim J (eds) Drug discrimination: applications to drug abuse research. USGPO, Washington, D.C., pp 25-31

Glennon RA (1999) Arylalkylamine drugs of abuse: an overview of drug discrimination studies. Pharmacol Biochem Behav 64:251-256

Glennon RA, Rosecrans JA, Young R, Gaines J (1979) Hallucinogens as discriminative stimuli: generalization of DOM to 5-methoxyN,N-dimethyltryptamine. Life Sci 24:993-997

Glennon RA, Young R, Rosecrans JA (1983) Antagonism of the effects of the hallucinogen DOM and the purported 5-HT agonist quipazine by 5-HT2 antagonists. Eur J Pharmacol 91:189-196

Glennon RA, Titeler M, McKenney JD (1984) Evidence for 5-HT2 involvement in the mechanism of action of hallucinogenic agents. Life Sci 35:2505-2511

Goodwin AK, Baker LE (2000) A three-choice discrimination procedure dissociates the discriminative stimulus effects of d-amphetamine and (+)-MDMA in rats. Exp Clin Psychopharmacol 8:415-423

Goodwin AK, Pynnonen DM, Baker LE (2003) Serotonergicdopaminergic mediation of MDMA's discriminative stimulus effects in a three-choice discrimination. Pharmacol Biochem Behav 74:987-995

Gouzoulis-Mayfrank E, Heekeren K, Neukirch A, Stoll M, Stock C, Obradovic M, Kovar KA (2005) Psychological effects of [S]ketamine and DMT: a double-blind cross-over study in healthy volunteers. Pharmacopsychiatry 38:301-311

Gouzoulis-Mayfrank E, Heekeren K, Neukirch A, Stoll M, Stock C, Daumann J, Obradovic M, Kovar KA (2006) Inhibition of return 
in the human 5-HT2A agonist and NMDA antagonist model of psychosis. Neuropsychopharmacology 31:431-441

Gozlan H, Thibault S, Laporte AM, Lima L, Hamon M (1995) The selective 5-HT1A antagonist radioligand [3H]WAY 100,635 labels both G-protein-coupled and free 5-HT1A receptors in rat brain membranes. Eur J Pharmacol 288:173-186

Griffiths RR, Richards WA, McCann U, Jesse R (2006) Psilocybin can occasion mystical-type experiences having substantial and sustained personal meaning and spiritual significance. Psychopharmacology 187:268-283

Heffter A (1896) Ueber Cacteenalkaloide. Ber Deut Chem Ges 29:897-898

Heffter A (1897) Uber Pellote. Arch Exptl Pathol Pharmakol 40:418-425

Herremans AH, van der Heyden JA, van Drimmelen M, Olivier B (1999) The 5-HT1A receptor agonist flesinoxan shares discriminative stimulus properties with some 5-HT2 receptor antagonists. Pharmacol Biochem Behav 64:389-395

Hirschhorn ID, Rosecrans JA (1974) A comparison of the effects of morphine and LSD. Pharmacol Biochem Behav 2:361-366

Hirschhorn ID, Winter JC (1971) Mescaline and lysergic acid diethylamide [LSD] as discriminative stimuli. Psychopharmacologia 22:64-71

Hoch PH, Cattell JP, Pennes HH (1952) Effects of mescaline and lysergic acid (d-LSD-25). Am J Psychiatry 108:579-584

Hofmann A (1959) Psychotomimetic drugs, chemical and pharmacological aspects. Acta Physiol Pharmacol Neerl 8:240-258

Hofmann A (1968) Psychotomimetic agents. In: Burger A (ed) Drugs affecting the central nervous system. Edward Arnold, London, pp 169-235

Hollister LE, Richards RK, Gillespie HK (1968) Comparison of tetrahydrocannabinol and synhexyl in man. Clin Pharmacol Ther 9:783-791

Hollister LE, Shelton J, Krieger G (1969a) A controlled comparison of lysergic acid diethylamide [LSD] and dextroamphetamine in alcoholics. Am J Psychiatry 125:1352-1357

Hollister LE, MacNichol MF, Gillespie HK (1969b) An hallucinogenic amphetamine analog (DOM) in man. Psychopharmacologia 14:62-73

Horita A, Nair X, Hamilton AE (1972) L- -methyl- -hydrazino- -(3,4dihydroxyphenyl)propionic acid: relative lack of antidecarboxylase activity in adrenals. Science 176:931-932

Isbell H, Wolbach AB, Winkler A, Miner EJ (1961) Cross tolerance between LSD and psilocybin. Psychopharmacologia 2:147-159

Isbell H, Gorodetzsky CW, Jasinski D, Claussen U, von Spulak F, Korte F (1967) Effects of (-)delta-9-trans-tetrahydrocannabinol in man. Psychopharmacologia 1967:184-188

Ismaiel AM, De Los Angeles J, Titeler M, Ingher S, Glennon RA (1993) Antagonism of the 1-[2,5-dimethoxy-4-methylphenyl]-2aminopropane stimulus with a newly identified $5-\mathrm{HT}_{2}$ versus 5- $\mathrm{HT}_{1 \mathrm{C}}$-selective antagonist. J Med Chem 36:2519-2525

Johanson C, Kilbey M, Gatchalian K, Tancer M (2006) Discriminative stimulus effects of 3,4-methylenedioxymethamphetamine (MDMA) in humans trained to discriminate between d-amphetamine, meta-chlorophenylpiperazine and placebo. Drug Alcohol Depend 81:27-36

Jones HE, Li H, Balster RL (1998) Failure of ibogaine to produce phencyclidine-like discriminative stimulus effects in rats and monkeys. Pharmacol Biochem Behav 59:413-418

Kamien J, Bickel W, Hughes J, Higgins S, Smith B (1993) Drug discrimination by humans compared to nonhumans: current status and future directions. Psychopharmacology 111:259-270

Katz JL, Chausmer AL, Elmer GI, Rubenstein M, Low MJ, Grandy DK (2003) Cocaine-induced locomotor activity and cocaine discrimination in dopamine $\mathrm{D}_{4}$ receptor mutant mice. Psychopharmacology 170:108-114
Kehne JH, Baron BM, Carr AA, Chaney SF, Elands J, Feldman DJ, Frank RA, van Giersbergen PL, McCloskey TC, Johnson MP, McCarty DR, Poirot M, Senyah Y, Siegel BW, Widmaier C (1996) Preclinical characterization of the potential of the putative atypical antipsychotic MDL 100,907 as a potent 5 -HT2A antagonist with a favorable CNS safety profile. J Pharmacol Exp Ther 277:968-981

Knight AR, Misra A, Quirk K, Benwell K, Revell D, Kennett G, Bickerdike M (2004) Pharmacological characterization of the agonist radioligands binding site of $5-\mathrm{HT}_{2 \mathrm{~A}}, 5-\mathrm{HT}_{2 \mathrm{~B}}$, and $5-\mathrm{HT}_{2 \mathrm{C}}$ receptors. N-S Arch Pharmacol 370:114-123

Koek W (1999) N-Methyl-D-aspartate antagonists and drug discrimination. Pharmacol Biochem Behav 64:275-281

Krall CM, Richards JB, Rabin RA, Winter JC (2007) Marked decrease of LSD-induced stimulus control in serotonin transporter knockout mice. Pharmacol Biochem Behav 88:349-357

Kuhn DM, White FJ, Appel JB (1978) The discriminative stimulus properties of LSD: mechanisms of action. Neuropharmacology $17: 257-263$

Leysen JE (1985) Serotonin receptor binding sites. In: Green AR (ed) Neuropharmacology of serotonin. Oxford Press, Oxford, pp 86-97

Li JX, Rice KC, France CP (2008) Discriminative stimulus effects of 1-[2,5-dimethoxy-4methylphenyl]-2-aminopropane in rhesus monkeys. J Pharmacol Exp Ther 324:827-833

Luby ED, Cohen BD, Rosenbaum G, Gottlieb JS, Kelly R (1959) Study of the new schizophrenomimetic drug L sernyl. Arch Neurol Psychiatry 81:363-368

Marona-Lewicka D, Nichols DE (1995) Complex stimulus properties of LSD: a drug discrimination study with alpha 2-adrenoceptor agonists and antagonists. Psychopharmacology 120:384-391

Marona-Lewicka D, Nichols DE (2007) Further evidence that the delayed temporal dopaminergic effects of LSD are mediated by a mechanism different than the first temporal phase of action. Pharmacol Biochem Behav 87:453-461

Marona-Lewicka D, Thisted RA, Nichols DE (2005) Distinct temporal phases in the behavioral pharmacology of LSD: dopamine $\mathrm{D}_{2}$ receptor-mediated effects in the rat and implications for psychosis. Psychopharmacology 180:427-435

Marona-Lewicka D, Chemel BR, Nichols DE (2008) Dopamine D4 receptor involvement in the discriminative stimulus effects in rats of LSD, but not the phenethylamine hallucinogen. Psychopharmacology. doi:10.1007/s00213-008-1238-0, Epub ahead of print

Martel JC, Leduc N, Ormiere AM, Faucilion V, Danty N, Culie C, Cussac D, Newman-Tancredti A (2007) WAY-100635 has high selectivity for $5-\mathrm{HT}_{1 \mathrm{~A}}$ versus dopamine $\mathrm{D}_{4}$ receptors. Eur $\mathrm{J}$ Pharmacol 574:15-19

Martin WR, Eades CG (1970) The action of tryptamine on the dog spinal cord and its relationship to the agonistic actions of LSDlike psychotogens. Psychopharmacologia 17:242-257

Meltzer HY, Simonovic M, Gudelsky GA (1983) Effects of pirenperone and ketanserin on rat prolactin secretion in vivo and in vitro. Eur J Pharmacol 19:83-89

Middaugh LD, Favara JP, Boggan WO, Stringer AJ (1988) Discriminative properties of phencyclidine in mice: generalization to ketamine and monohydroxy metabolites. Psychopharmacology 96:381-384

Morris K (2008) Research on psychedelics moves into the mainstream. Lancet 371:1491-1492

Nagai T, Murai R, Matsui K, Kamei H, Noda Y, Furukawa H, Nabeshima T (2008) Aripiprazole ameliorates PCP-induced impairment of recognition memory through dopamine $\mathrm{D}(1)$ and serotonin 5-HT1A receptors. Psychopharmacology. doi:10.1007/ s00213-008-1240-6, Epub ahead of print

Nichols DE (2004) Hallucinogens. Pharmacol Ther 101:131-181

Nichols DE, Nichols CD (2008) Serotonin receptors. Chem Rev 108:1614-1641 
Nielsen EB (1985) Discriminative stimulus properties of lysergic acid diethylamide in the monkey. J Pharmacol Exp Ther 234:244-249

Patil ST, Zhang L, Martenyi F, Lowe SL, Jackson KA, Andreev BV, Avedisova AS, Bardenstein LM, Gurovich IY, Marazova MA, Mosolov SN, Neznanov NG, Reznik AM, Smulevich AB, Tochilov VA, Johnson BG, Monn JA, Schoepp DD (2007) Activation of mGlu2/3 receptors as a new approach to treat schizophrenia: a randomized Phase 2 clinical trial. Nat Med 13:1102-1107

Pauwels PJ, Van Gompel P, Leysen JE (1993) Activity of serotonin receptor agonists, partial agonists, and antagonists at cloned human 5-HT1A receptors that are negatively coupled to adenylate cyclase in permanently transfected HeLa cells. Biochem Pharmacol 45:375-383

Pazos A, Hoyer D, Palacios JM (1984) The binding of serotonergic ligands to the porcine choroid plexus: characterization of a new type of serotonin recognition site. Eur J Pharmacol 106(3):539546, Nov 27

Peroutka SJ, Snyder SH (1979) Multiple serotonin receptors: differential binding of $\left[{ }^{3} \mathrm{H}\right]-5$-hydroxytryptamine, $\left[{ }^{3} \mathrm{H}\right]$ lysergic acid diethylamide, and $\left[{ }^{3} \mathrm{H}\right]$ spiroperidol. Molecular Pharmacol 16:687-699

Rabin RA, Doat M, Winter JC (2000) Role of serotonergic 5-HT $2 \mathrm{~A}$ receptors in the psychotomimetic actions of phencyclidine. Int $\mathrm{J}$ Neuropsychopharmacol 3:333-338

Rabin RA, Regina MJ, Doat MM, Winter JC (2002) 5- $\mathrm{HT}_{2 \mathrm{~A}}$ receptorstimulated phosphoinositide hydrolysis in the stimulus effects of hallucinogens. Pharmacol Biochem Behav 72:29-37

Rapport M (1949) Serum vasoconstrictor (serotonin) the presence of creatinine in the complex; a proposed structure of the vasoconstrictor principle. J Biol Chem 180:961-969

Reissig CJ, Eckler JR, Rabin RA, Winter JC (2005) The 5- $\mathrm{HT}_{1 \mathrm{~A}}$ receptor and the stimulus effects of LSD in the rat. Psychopharmacology 182:197-204

Richelson E, Souder T (2000) Binding of antipsychotic drugs to human brain receptors focus on newer generation compounds. Life Sci. 68:29-39

Rosecrans JA, Glennon RA (1979) Drug-induced cues in studying mechanisms of drug action. Neuropharmacology 18:981-989

Sai-Halisz A, Brunecker G, Szara S (1958) Dimethyltryptamine: a new psycho-active drug. Psychiatr Neurol 35:285-301

Sanders-Bush E, Burris KD, Knoth K (1988) Lysergic acid diethylamide and 2,5-dimethoxy-4-methylamphetamine are partial agonists at serotonin receptors linked to phosphoinositide hydrolysis. J Pharmacol Exp Ther 246:924-928

Schechter MD, Rosecrans JA (1972) LSD as a discriminative cue: drugs with similar stimulus properties. Psychopharmacologia 26:313-316

Schneider CW, Chenoweth MB (1970) Effects of hallucinogenic and other drugs on the nest-building behavior of mice. Nature 225:1262-1263

Schreiber R, Brocco M, Millan MJ (1994) Blockade of the discriminative stimulus effects of DOI by MDL 100,907 and the 'atypical' antipsychotics, clozapine and risperidone. Eur J Pharmacol 264:99-102

Schreiber R, Brocco M, Audinot V, Gobert A, Veiga S, Millan MJ (1995) (1-(2,5-dimethoxy-4 iodophenyl)-2-aminopropane)-induced headtwitches in the rat are mediated by 5-hydroxytryptamine (5-HT) $2 \mathrm{~A}$ receptors: modulation by novel $5-\mathrm{HT} 2 \mathrm{~A} / 2 \mathrm{C}$ antagonists, D1 antagonists and 5-HT1A agonists. J Pharmacol Exp Ther 273:101-112

Schultes RE, Hofmann A (1980) The botany and chemistry of hallucinogens. Charles C. Thomas, Springfield

Seong E, Seasholtz AF, Burmeister M (2002) Mouse models of psychiatric disorders. Trends Genet 18:643-650

Shannon EE, Shelton KL, Vivian JA, Yount I, Morgan AR, Homanics GE, Grant KA (2004) Discriminative stimulus effects of ethanol in mice lacking the gamma-aminobutyric acid type A receptor delta subunit. Alcoholism Clin Expt Res 28:906-913

Shulgin A, Shulgin A (1991) PiHKAL, a chemical love story. Transform Press, Berkeley

Shulgin A, Shulgin A (1997) TiHKAL, the continuation. Transform Press, Berkeley

Silva MT, Calil HM (1975) Screening hallucinogenic drugs: systematic study of three behavioral tests. Psychopharmacologia 42:63-71

Silverman PB, Ho BT (1980) The discriminative stimulus properties of 2,5-dimethoxy-4-methylamphetamine (DOM): differentiation from amphetamine. Psychopharmacology 68:209-215

Smith RL, Barrett RJ, Sanders-Bush E (2003) Discriminative stimulus properties of 1-2(2,5-dimethoxy-4-iodophenyl)-2-aminopropane $[(+) \mathrm{DOI}]$ in C57BL/6J mice. Psychopharmacology 166:61-68

Smythies JR, Sykes EA (1964) The effect of mescaline upon the conditioned avoidance response in the rat. Psychopharmacologia 6:163-172

Snigdha S, Neill JC (2008) Improvement of phencyclidine-induced social behavior deficits in rats: involvement of 5-HT1A receptors. Behav Brain Res 191:26-31

Snoddy AM, Tessel RE (1983) Nisoxetine and amphetamine share discriminative stimulus properties in mice. Pharmacol Biochem Behav 19:205-210

Snyder SH, Faillace L, Hollister L (1968) 2,5-Dimethoxy-4methylamphetamine: new hallucinogenic drug. Science 159:1492

Spath E (1919) Uber die Anhalonium-Alkaloide, I. Anhalin und Mezcalin. Monograph. Fur Chem 40:129-152

Spencer DG Jr, Glaser T, Traber J (1987) Serotonin receptor subtype mediation of the interoceptive discriminative stimuli induced by 5-methoxy- $N, N$-dimethyltryptamine. Psychopharmacology 93:158-166

Stolerman IP, Kamien JB (2004) Drug discrimination bibliographic database. www.dd-database.org

Stolerman IP, Chamberlain S, Bizarro L, Fernandes C, Schalkwyk L (2004) The role of nicotinic alpha7 subunits in nicotine discrimination. Neuropharmacology 46:363-371

Strassman RJ (1991) Human hallucinogenic drug research in the United States: a present-day case history and review of the process. J Psychoactive Drugs 23:29-38

Strassman RJ, Qualls CR, Uhlenhuth EH, Kellner RK (1994) Dose response study of $N, N$-dimethyltryptamine in humans. Arch Gen Psychiatr 51:98-108

Szara S (1956) Dimethyltryptamine: its metabolism in man; the relation of its psychotic effect to serotonin metabolism. Experientia 12:441-442

Szara S (1957) The comparison of the psychotic effects of tryptamine derivatives with the effects of mescaline and LSD-25 in selfexperiments. In: Garattini S, Ghetti V (eds) Psychotropic drugs. Elsevier, Amsterdam

Torres M, Repke D (2006) Anadenanthera: visionary plant of ancient South America. The Haworth Herbal Press, New York, pp 143-186

Uyeno ET (1969) Alteration of a learned response of the squirrel monkey by hallucinogens. Int J Neuropharmacol 8:245-253

Uyeno ET, Mitoma C (1969) The relative effectiveness of several hallucinogens in disrupting maze performance by rats. Psychopharmacologia 16:73-80

Vollenweider FX, Gamma A, Bar T, Babler A, Vogel H, Hell D (1996) Ketanserin, a 5-HT2 antagonist, but not haloperidol, effectively blocks psilocybin-induced model psychosis in healthy volunteers. WPA Abstract book, 116

Vollenweider FX, Vollenweider-Scherpenhuyzen MFI, Babler A, Vogen H, Hell D (1998a) Psilocybin induces schizophrenia-like psychosis in humans via a serotonin-2 agonist action. NeuroRep 9:3897-3902 
Vollenweider FX, Gamma A, Liechti M, Huber T (1998b) Psychological and cardiovascular effects and short-term sequelae of MDMA ["Ecstasy"] in MDMA-naïve healthy volunteers. Neuropsychopharmacol 19:241-251

Vollenweider FX, Vontobel P, Hell D, Leenders KL (1999) 5-HT modulation of dopamine release in basal ganglia in psilocybininduced psychosis in man-a PET study with $\left[{ }^{11} \mathrm{C}\right]$ raclopride. Neuropharmacol 20:424-433

Webster (1993) Webster's third new international dictionary of the English language unabridged. Merriam Webster, Springfield

Weinberg AM (1972) Science and trans-science. Science 177:211-221

White FJ, Simmons MA, West KB, Holohean AM, Appel JB (1980) The effect of serotonin depletion on the discriminability of LSD. Pharmacol Biochem Behav 13:569-574

Willins DL, Meltzer HY (1997) Direct injection of 5-HT2A receptor agonists into the medial prefrontal cortex produces a head-twitch response in rats. J Pharmacol Exp Ther 282:699-706

Winter JC (1971) Tolerance to a behavioral effect of lysergic acid diethylamide and cross-tolerance to mescaline in the rat: absence of a metabolic component. J Pharmacol Exp Ther 178:625-630

Winter JC (1974) Hallucinogens as discriminative stimuli. Fed Proc 33:1825-1832

Winter JC (1975) Blockade of the stimulus properties of mescaline by a serotonin antagonist. Arch Int Pharmacodyn Ther 214:250-253

Winter JC (1978) Stimulus properties of phenethylamine hallucinogens and lysergic acid diethylamide: the role of 5-hydroxytryptamine. J Pharmacol Exp Ther 204:416-423

Winter CA, Flataker L (1956) Effects of LSD upon performance of trained rats. PSEBM 92:285-289

Winter JC, Gessner PK (1968) Phenoxybenzamine antagonism of tryptamines, their indene isosteres, and 5-hydroxytryptamine in the rat stomach fundus preparation. J Pharmacol Exp Ther 162:286-293

Winter JC, Fiorella DJ, Timineri DM, Filipink RA, Helsley SE, Rabin RA (1999) Serotonergic receptor subtypes and hallucinogen-induced stimulus control. Pharmacol Biochem Behav 64:283-293

Winter JC, Doat M, Rabin RA (2000a) Potentiation of DOM-induced stimulus control by non-competitive NMDA antagonists. A link between the glutamatergic and serotonergic hypotheses of schizophrenia. Life Sci 68:337-344

Winter JC, Filipink RF, Timineri D, Helsley SE, Rabin RA (2000b) The paradox of 5-methoxy- $N, N$-dimethyltryptamine: a hallucinogen which induces stimulus control via $5-\mathrm{HT}_{1 \mathrm{~A}}$ receptors. Pharmacol Biochem Behav 65:75-82

Winter JC, Eckler JR, Rabin RA (2004) Serotonergic/glutamatergic interactions: the effects of $\mathrm{mGlu}_{2 / 3}$ receptor ligands in rats trained with LSD and PCP as discriminative stimuli. Psychopharmacology 172:233-240

Winter JC, Kiers AK, Zimmerman MD, Reissig CJ, Eckler JR, Ullrich T, Rice KC, Rabin RA, Richards JB (2005a) The stimulus properties of LSD in C57BL/J mice. Pharmacol Biochem Behav 81:830-837

Winter JC, Eckler JR, Rice KC, Rabin RA (2005b) Serotonergicglutamatergic interactions: potentiation of phencyclidine-induced stimulus control by citalopram. Pharmacol Biochem Behav 81:694-700

Winter JC, Rice KC, Amorosi DJ, Rabin RA (2007) Psilocybininduced stimulus control in the rat. Pharmacol Biochem Behav $87: 472-480$

Wolbach AB, Isbell H, Miner EJ (1962a) Cross tolerance between mescaline and LSD-25, with a comparison of the mescaline and LSD reactions. Psychopharmacologia 12:1-14

Wolbach AB, Isbell H, Miner EJ (1962b) Comparison of psilocin with psilocybin, mescaline and LSD-25. Psychopharmacologia. 3:219-223

Wooley DW, Shaw E (1954) A biochemical and pharmacological suggestion about certain mental disorders. PNAS [USA] 40:228-235

Young R, Rosecrans JA, Glennon RA (1982) Comparative discriminative stimulus effects of 5-methoxy- $N, N$-dimethyltryptamine and LSD. Life Sci 30:2057-2062

Young R, Rosecrans JA, Glennon RA (1983) Behavioral effects of 5-methoxy- $N, N$-dimethyltryptamine and dose-dependent antagonism by BC-105. Psychopharmacology 80:156-160

Young R, Rosecrans JA, Glennon RA (1986) Further studies on the dosedependent stimulus properties of 5-methoxy- $N, N$-dimethyltryptamine. Pharmacol Biochem Behav 25:1207-1210 